\title{
Species composition and density estimates of the anurofauna of a site within the northernmost large Atlantic Forest remnant (Parque Estadual do Desengano) in the state of Rio de Janeiro, Brazil
}

\author{
Carla da Costa Siqueira ${ }^{1,2,5}$, Davor Vrcibradic ${ }^{1,3}$, Mauricio Almeida-Gomes ${ }^{1}$, \\ Vanderlaine Amaral Menezes ${ }^{1}$, Vitor Nelson Teixeira Borges-Junior ${ }^{1}$, \\ Fábio Haruki Hatano ${ }^{1,4}$, Jorge Antônio Lourenço Pontes ${ }^{1}$, \\ Pablo Goyannes-Araújo ${ }^{1}$, Diego Medeiros Guedes ${ }^{1}$, \\ Monique van Sluys ${ }^{1} \&$ Carlos Frederico Duarte Rocha ${ }^{1}$ \\ ${ }^{I}$ Departamento de Ecologia, Universidade do Estado do Rio de Janeiro - UERJ, \\ Rua São Francisco Xavier, 524, CEP 20550-011, Rio de Janeiro, RJ, Brazil \\ ${ }^{2}$ Programa de Pós-Graduação em Ecologia, Instituto de Biologia, Universidade Federal do Rio de Janeiro - UFRJ, \\ Av. Carlos Chagas Filho, 373, Bloco A, Cidade Universitária, Cep 21941-902, Rio de Janeiro, RJ, Brazil \\ ${ }^{3}$ Departamento de Zoologia, Universidade Federal do Estado do Rio de Janeiro - UNIRIO, \\ Av. Pasteur, 458, Urca, CEP 22240-290, Rio de Janeiro, RJ, Brazil \\ ${ }^{4}$ Universidade do Estado do Pará - UEPA, \\ Av. Hiléia, sn, Agrópolis do Incra, CEP 68503-120, Marabá, PA, Brazil \\ ${ }^{5}$ Corresponding author: Carla da Costa Siqueira, e-mail: carlacsiqueira@yahoo.com.br
}

SIQUEIRA, C.C., VRCIBRADIC, D., ALMEIDA-GOMES, M., MENEZES, V.A., BORGES-JUNIOR, V.N.T., HATANO, F.H., PONTES, J.A.L., GOYANNES-ARAÚJO, P., GUEDES, D.M., van SLUYS, M. \& ROCHA, C.F.D. Species composition and density estimates of the anurofauna of a site within the northernmost large Atlantic Forest remnant (Parque Estadual do Desengano) in the state of Rio de Janeiro, Brazil. Biota Neotrop. 11(4): http://www.biotaneotropica.org.br/v11n4/en/abstract?article+bn03311042011

\begin{abstract}
We present data on species composition, relative abundance and estimated densities for leaf-litter anuran amphibians from an Atlantic Forest area within the Parque Estadual do Desengano, in the state of Rio de Janeiro, Brazil, based on results of a short-term survey carried out during the winter at altitudes of 1000-1500 m. Three sampling methods were used: plot sampling, visual encounter surveys (VES; performed during the day, at the twilight, and at night), and pitfall traps. We recorded 13 species, with the direct-developer Ischnocnema parva (Girard, 1853) being the most abundant. Most frogs (ca. $90 \%$ of all individuals) sampled by VES were captured during the crepuscular and nocturnal periods. The estimated density of the local leaf-litter frog assemblage based on plot sampling was 13.2 ind. $100 \mathrm{~m}^{-2}$, which is one of the highest values currently reported for Atlantic Rainforest areas. This is the first study analyzing the anuran fauna of the Parque Estadual do Desengano and adds to the knowledge of the fauna of the northern region of the state of Rio de Janeiro, which is still poorly studied. Keywords: amphibian, Atlantic Forest, density estimate, southeastern Brazil, survey.
\end{abstract}

SIQUEIRA, C.C., VRCIBRADIC, D., ALMEIDA-GOMES, M., MENEZES, V.A., BORGES-JUNIOR, V.N.T., HATANO, F.H., PONTES, J.A.L., GOYANNES-ARAÚJO, P., GUEDES, D.M., van SLUYS, M. \& ROCHA, C.F.D. Composição de espécies e estimativa de densidade da anurofauna em uma área dentro do mais setentrional dos grandes remanescentes de Mata Atlântica (Parque Estadual do Desengano) do Estado do Rio de Janeiro, Brasil. Biota Neotrop. 11(4): http://www.biotaneotropica.org.br/v11n4/pt/abstract?article+bn03311042011

Resumo: Apresentamos dados sobre a composição de espécies, abundância relativa e densidade estimada para anfíbios anuros de serrapilheira de uma área de Mata Atlântica no Parque Estadual do Desengano, no Estado do Rio de Janeiro, Brasil, com base em resultados de um estudo de curto prazo realizado durante o inverno a altitudes de 1000-1500 m. Três métodos de amostragem foram utilizados: amostragem em parcelas, encontros visuais (realizados durante o dia, no crepúsculo e à noite) e armadilhas de queda. Foram registradas 13 espécies, com Ischnocnema parva (Girard, 1853), uma forma com desenvolvimento direto, sendo a mais abundante. A maioria dos anuros (ca. $90 \%$ de todos os indivíduos) amostrados pelo método de encontros visuais foi coletada durante os períodos crepuscular e noturno. A densidade estimada para anuros de serrapilheira foi de 13,2 ind.100 $\mathrm{m}^{-2}$, que é um dos valores mais altos atualmente registrados para áreas de Mata Atlântica. Este é o primeiro estudo que analisa a fauna de anuros do Parque Estadual do Desengano e contribui para o conhecimento da fauna da região norte do estado do Rio de Janeiro, que ainda é pouco estudada.

Palavras-Chave: anfíbios, Mata Atlântica, densidade estimada, sudeste do Brasil, inventários. 


\section{Introduction}

The Atlantic Forest biome is considered one of the world's hotspots for conservation due to its high biological diversity, rates of endemism for several groups of organisms, number of endangered species, and strong deforestation pressure (Myers et al. 2000). The Atlantic Forest once extended for over $4000 \mathrm{~km}$ along the Brazilian coast, but after centuries of deforestation, it has been drastically reduced to $11-16 \%$ of its original cover (Ribeiro et al. 2009). Most of what remains of the Atlantic Forest is composed of relatively small fragments (Morellato \& Haddad 2000, Ribeiro et al. 2009), and the population growth and increasing urbanization within the biome's limits represents a constant threat. The state of Rio de Janeiro is one of the most populous and densely urbanized in the country, nevertheless it still contains several forest remnants which together represent about $20 \%$ of its original forest cover (Rocha et al. 2003, Bergallo et al. 2009). Preservation of such remnants is of vital importance, as the state harbors populations of several endangered animal species (Bergallo et al. 2000), and has a relatively high rate of endemism, particularly for terrestrial vertebrates (Rocha et al. 2003, 2004).

A recent analysis concluded that knowledge about species distribution within the state of Rio de Janeiro is considerably heterogeneous (Bergallo et al. 2009). For example, in the northern region of the state, there are almost no data about the composition and distribution of the fauna, which hinders the adequate management of the regional biodiversity (Rocha et al. 2003, Bergallo et al. 2009). Data on the fauna from forested areas in that region include surveys of insects (e.g. Tonhasca Junior et al. 2002, Moço et al. 2005, Gonçalves \& Brandão 2008) and mammals (Vaz 1998, Modesto et al. 2008) at the Parque Estadual do Desengano, of birds in Campos dos Goytacazes municipality (Piratelli et al. 2005), of bats in Miracema municipality
(Esbérard et al. 2010), and of anuran amphibians in a small fragment in Cambuci municipality (Almeida-Gomes et al. 2010). Most studies about anuran amphibian assemblages/guilds in forested areas of Rio de Janeiro have been conducted in the central and southern portions of the state (e.g. Rocha et al. 2000, 2001, 2007, Van Sluys et al. 2007, Almeida-Gomes et al. 2008, Carvalho-e-Silva et al. 2008, Silva et al. 2008, Salles et al. 2009, Siqueira et al. 2009, 2011). Although the Parque Estadual do Desengano constitutes the largest rainforest remnant in the northern portion of Rio de Janeiro State (Rocha et al. 2003, Bergallo et al. 2009), there is no published information on the anurofauna from that locality. Thus, in the present study, we present preliminary data on some parameters of the anuran community from the Parque Estadual do Desengano, such as species composition, richness, density and relative abundances.

\section{Material and Methods}

\section{Study area}

The study was carried out within the Parque Estadual do Desengano (PED), a conservation unit encompassing parts of the municipalities of Santa Maria Madalena, São Fidélis and Campos dos Goytacazes, in Rio de Janeiro State, southeastern Brazil (Figure 1). Created in 1983, the PED (22,400 ha) represents the northernmost large remnant of Atlantic Forest in the State, with large patches of little disturbed forests present mainly at higher elevations. The park reaches $1760 \mathrm{~m}$ of altitude at its highest peak (the Pico do Desengano). Annual temperature in the area varies between 12 and $30{ }^{\circ} \mathrm{C}$ (averaging $16.7^{\circ} \mathrm{C}$ ), and mean annual precipitation is $1471 \mathrm{~mm}$ (Attias et al. 2009).

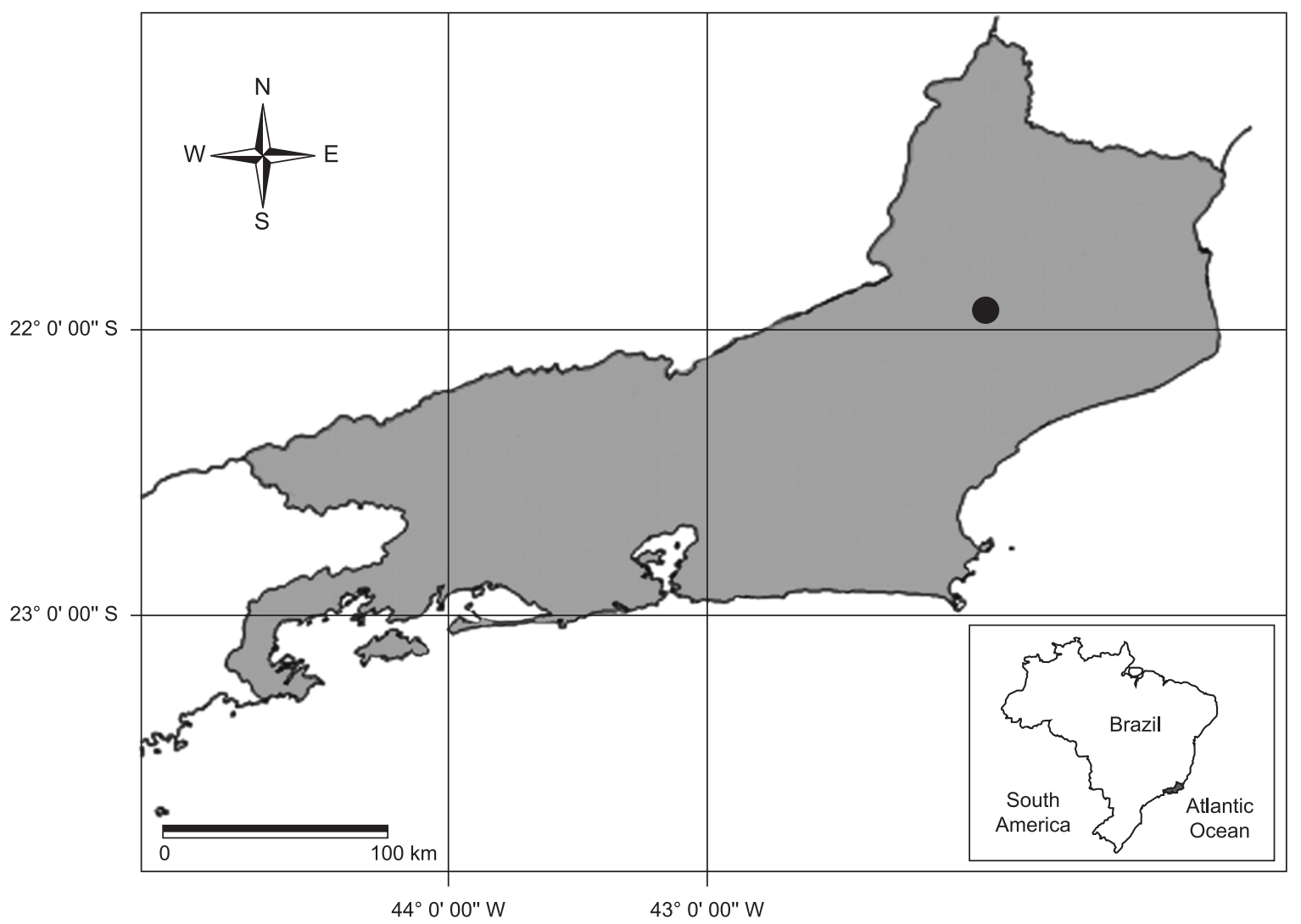

Figure 1. Map showing the location of the Parque Estadual do Desengano (solid circle) in the state of Rio de Janeiro (shaded). 


\section{Methodology and analyzes}

Fieldwork was conducted during early June 2006 (sampling with pitfalls began in late May). Surveys were carried out at altitudes between 1060 and $1500 \mathrm{~m}$ in an area of the PED located in the municipality of Santa Maria Madalena (21 ${ }^{\circ} 52^{\prime} \mathrm{S}, 41^{\circ} 54^{\prime} \mathrm{W}$ ), using three sampling methods: plots (Jaeger \& Inger 1994), visual encounter surveys (Crump \& Scott 1994), and pitfall traps with drift fences (Corn 1994).

For the plot method, 30 quadrats of $5 \times 5 \mathrm{~m}$ were established on the forest floor during the afternoon, totaling $750 \mathrm{~m}^{2}$ of area sampled. The corners of each plot were marked with wooden stakes and the area inside was enclosed with a $50 \mathrm{~cm}$ high soft plastic fence, whose base was buried or attached to the ground. After sunset, each plot was carefully searched for about half an hour by a crew of five persons using headlamps, moving on hands and knees, side-by-side. During the searches the leaf-litter was stirred with hand rakes, and leaves, stones and fallen branches were overturned; rock crevices and fissures among tree roots were also checked for frogs. Plot sampling was performed during five consecutive days, with six quadrats done per night.

For visual encounter surveys (VES), 150 time-constrained transects of 30 minutes each were carried out by ten people, totaling 75 hours of sampling effort. Equal numbers of transects (50) were surveyed during the day, at dusk and at night. During transects, the observer moved at a slow walking pace, carefully searching all types of potential microhabitats for frogs.

Three pitfall trap systems were established and remained open for a total of 11 days. Each system consisted of ten 30-liter buckets buried on the ground up to their rims and set ca. $5 \mathrm{~m}$ apart, with soft plastic drift fences about $50 \mathrm{~cm}$ high extended between them. Six buckets were set in line and the other four were placed at opposite ends of the fence, perpendicular to the main axis. Pitfalls were checked once per day for captured animals, always in the morning.

All frogs found by the three sampling methods were collected and identified. Additionally, individuals found opportunistically during casual encounters (i.e. outside of the sampling protocol) were also recorded. For an estimate of species composition and richness of the leaf litter frog community, the species recorded by all three sampling methods plus those collected during casual encounters were considered. Estimates of leaf litter frog density (ind/100 $\mathrm{m}^{2}$ ) were done based on the data obtained by plot sampling. Voucher specimens of frog species collected during the study were deposited at the amphibian collections of the Museu Nacional, Rio de Janeiro (MNRJ) and of the Universidade Federal do Estado do Rio de Janeiro (UNIRIO) (Appendix 1).

\section{Results}

Thirteen frog species belonging to five families were recorded during the study, of which three were recorded outside of the sampling protocol (Table 1). The latter includes two hylids, identified as Aplastodiscus cf. arildae (Cruz and Peixoto, 1987) and Bokermannohyla sp. (gr. circumdata), that were collected as tadpoles and later metamorphosed in a terrarium; unfortunately, they both died before reaching adult size, and thus a positive identification was not possible. A few individuals of the genus Hylodes (gr. lateristrigatus) were visualized during occasional encounters, but we did not capture any specimens.

The most abundant species recorded during the study was the direct-developing frog Ischnocnema parva (Girard, 1853) (comprising $81 \%$ of all individuals collected), followed by the treefrog Scinax v-signatus (Lutz, 1968) (6.6\%).

A total of 99 individuals belonging to four frog species were found in the plots (Table 1). The number of frogs per plot ranged from zero (4/30 or $13.3 \%$ of all plots) to ten $(1 / 30$ or $3.3 \%$ of all plots) with a mean of $3.3 \pm 2.4$ frogs per plot. The estimated overall frog density of the local leaf litter frog assemblage was 13.2 ind. $100 \mathrm{~m}^{-2}$. Individually, the highest densities were those of I. parva (12.3 ind.100 $\left.\mathrm{m}^{-2}\right)$, followed by Ischnocnema guentheri (Steindachner, 1864) (0.7 ind.100 $\left.\mathrm{m}^{-2}\right)$, and those two species

Table 1. Number of frogs of each species recorded by visual encounter surveys at each period of the day (diurnal, crepuscular and nocturnal) and by plot sampling at the Atlantic Rainforest of the Parque Estadual do Desengano, in southeastern Brazil.

\begin{tabular}{|c|c|c|c|c|c|}
\hline \multirow[t]{2}{*}{ Species } & \multicolumn{3}{|c|}{ Visual encounter survey } & \multirow[t]{2}{*}{ Plot } & \multirow[t]{2}{*}{ Total } \\
\hline & Diurnal & Crespuscular & Nocturnal & & \\
\hline BRACHYCEPHALIDAE & - & - & - & - & - \\
\hline Brachycephalus sp. & 1 & - & 1 & 1 & 3 \\
\hline Ischnocnema guentheri (Steindachner, 1864) & - & - & - & 5 & 5 \\
\hline Ischnocnema octavioi (Bokermann, 1965) & - & 1 & - & - & 1 \\
\hline Ischnocnema parva (Girard, 1853) & 3 & 12 & 4 & 92 & 111 \\
\hline CYCLORAMPHIDAE & - & - & - & - & - \\
\hline Proceratophrys melanopogon (Miranda-Ribeiro, 1926) & - & 1 & - & - & 1 \\
\hline BUFONIDAE & - & - & - & - & - \\
\hline Rhinella icterica (Spix, 1824) & - & - & 1 & - & 1 \\
\hline HYLIDAE & - & - & - & - & - \\
\hline Aplastodiscus cf. arildae* (Cruz and Peixoto, 1987) & - & - & - & - & - \\
\hline Bokermannohyla sp.* & - & - & - & - & - \\
\hline Hypsiboas polytaenius (Cope, 1870) & - & - & 1 & - & 1 \\
\hline Phasmahyla guttata (Lutz, 1924) & - & - & 1 & - & 1 \\
\hline Scinax flavoguttatus (Lutz and Lutz, 1939) & - & - & 3 & - & 3 \\
\hline Scinax v-signatus (Lutz, 1968) & - & 7 & 1 & 1 & 9 \\
\hline HYLODIDAE & - & - & - & - & - \\
\hline Hylodes sp.* & - & - & - & - & - \\
\hline TOTAL & 4 & 21 & 12 & 99 & 136 \\
\hline
\end{tabular}

Species recorded only outside of the sampling methods are marked with an asterisk $(*)$. 
together comprised about $98 \%$ of individuals found in plots. Both Brachycephalus sp. and S. v-signatus had a population density of 0.1 ind $.100 \mathrm{~m}^{-2}$ (the latter species was represented by an individual found inside a ground bromeliad). Nine frog species were recorded during transect samplings, with Ischnocnema parva being the most abundant $(\mathrm{N}=19$, or $51.4 \%$ of all individuals found; Table 1$)$. Almost all frog species recorded during transects were found at night ( $\mathrm{N}=7$ species), whereas Brachycephalus sp. and I. parva were also found during diurnal samplings (Table 1). Most individuals were found during the crepuscular $(\mathrm{N}=21$, or $56.8 \%$ of all individuals sampled) and nocturnal ( $\mathrm{N}=12$, or $32.4 \%)$ transect searches (Table 1). No frogs were captured in pitfall traps.

\section{Discussion}

The only previous study of rainforest amphibian assemblages in the northern part of the state of Rio de Janeiro was done in a small (ca. 1000 ha) fragment in Cambuci municipality (AlmeidaGomes et al. 2010). In that study, using the same sampling methods that we used in the present one, 20 species of frogs were recorded. Nevertheless, only 11 species (or $55 \%$ of the species sampled) were found within the forest fragment, with the remaining ones being associated with open and disturbed habitats at its border or in the surrounding matrix (Almeida-Gomes et al. 2010). In the present study we recorded a similar number of species (13) using a similar sampling effort, but the PED has a much larger and less disturbed forest area when compared to the fragment studied in Cambuci. As our study was carried out during the winter at altitudes above $1000 \mathrm{~m}$, it is possible that some species may have reduced or suspended their activity because of the low temperatures, thus escaping detection. Temperature, among other environmental variables, is known to restrict activity in frogs in different environments (e.g., Licht 1969, Pough et al. 1983, Navas 1996), including the Atlantic Rainforest (Hatano et al. 2002, Boquimpani-Freitas et al. 2002, 2007, AlmeidaGomes et al. 2007). It is possible that some frog taxa not recorded by us such as Haddadus binotatus (Spix, 1824), Zachaenus parvulus (Girard, 1853), and/or some Ischnocnema of the lactea group may occur in our study area, as they have been recorded by Siqueira et al. (2011) in an area of similar altitude in the municipality of Nova Friburgo, ca. $80 \mathrm{~km}$ southwest from the PED. We consider probable that a survey carried out during the spring or summer would yield greater frog richness, considering the good state of preservation of the forested area encompassed by the PED.

The estimated overall frog density of the local leaf litter frog assemblage was relatively high when compared to those found for other sites within the Atlantic Rainforest (Giaretta et al. 1997, 1999, Rocha et al. 2001, 2007, Almeida-Gomes et al. 2008, 2010), with one exception (Siqueira et al. 2009). However, 93\% of the frogs found in plots represented a single species, so that the high frog density observed basically reflects the high local abundance of I. parva. Indeed, this small direct-developing frog numerically dominated the anuran assemblage at PED (as also evidenced by the VES methodology). Species with direct development usually are numerically dominant in Neotropical litter frog assemblages (e.g., Scott Junior 1976, Lieberman 1986, Fauth et al. 1989, Giaretta et al. 1997, 1999, Rocha et al. 2001, 2007, Van Sluys et al. 2007, Siqueira et al. 2009, Almeida-Gomes et al. 2008, 2010). Direct-developing frogs may be more widely distributed within the forest because they are independent of water bodies for reproduction, whereas species with water-dependent reproduction may be limited by the proximity of water bodies (e.g., Heyer \& Berven 1973, Scott Junior 1976).
Most frog species at the PED were sampled by the VES method and six species [I. octavioi (Bokermann, 1965), Proceratophrys melanopogon (Miranda-Ribeiro, 1926), Rhinella icterica (Spix, 1824), Hypsiboas polytaenia (Cope, 1870), Phasmahyla guttata (Lutz, 1924) and Scinax flavoguttatus (Lutz and Lutz, 1939)] were recorded only by this methodology. Only one species (I. guentheri) was sampled exclusively in plots and another three (Aplastodiscus cf. arildae, Bokermannohyla sp. and Hylodes sp.) were recorded opportunistically during occasional encounters. No frogs were captured by pitfall traps at the PED. We do not know if the size of buckets may have influenced capture efficiency (i.e. larger buckets could be more efficient in preventing more individuals from escaping). However, some studies have suggested that bucket size may not affect significantly the richness and abundance of amphibians and reptiles sampled by pitfall traps in tropical forests (Webb 1999, Ribeiro-Júnior et al. 2011). Nevertheless, pitfall traps have not proven to be an efficient method for short-term herpetofaunal inventories, at least in Atlantic Forest areas (e.g., Almeida-Gomes et al. 2008, 2010, Siqueira et al. 2009). In our study, the VES method was the most efficient method for sampling frogs. Moreover, frogs were captured mainly during the crepuscular and nocturnal periods (ca. $90 \%$ of all individuals). This trend has been observed in some previous studies that analyzed the activity of frogs in other Brazilian rainforest areas (e.g., Rocha et al. 2000, 2007, Almeida-Gomes et al. 2008, 2010, Menin et al. 2008, Siqueira et al. 2009). Thus, anuran surveys in Neotropical forests should be preferentially carried out during and after sunset, to maximize encounter rates (Rocha et al. 2000, Menin et al. 2008).

The PED currently represents the largest protected area of Atlantic Rainforest in the northern portion of Rio de Janeiro State (Rocha et al. 2003). This is the first study analyzing anuran composition of the Parque Estadual do Desengano and represents an addition to the knowledge of the fauna of the northern region of Rio de Janeiro State, which is still poorly studied. Although the present study represents a short-term survey carried out at a comparatively small area within this reserve, it suggests that the whole area encompassed by the park (over 22,000 ha) may harbor a considerable anuran richness and numerous sites where the forest floor is densely populated by frogs. This, and the fact that one of the species recorded during the study (Brachycephalus sp.) is currently undescribed (J. P. Pombal Jr., pers. comm.), reinforces the importance of the Parque Estadual do Desengano as an important conservation unit for anuran species.

\section{Acknowledgements}

The Critical Ecosystem Partnership Fund (CEPF) at Conservation International and the Conselho Nacional de Desenvolvimento Científico e Tecnológico - CNPq provided financial support for the study. The latter also provided research grants to C. F. D. Rocha (Processes $n^{\circ} 304791 / 2010-5$ and 470265/2010-8) and to M. Van Sluys (Process no 307773/2008-6). C. F. D. Rocha also benefited from the "Cientistas do Nosso Estado" Program from Fundação Carlos Chagas Filho de Amparo à Pesquisa do Estado do Rio de Janeiro - FAPERJ (process E-26/102.404.2009). Graduate fellowships were granted to M. A. Gomes and V. N. T. Borges-Junior from the Coordenação de Aperfeiçoamento de Pessoal de Nível Superior (CAPES), to C. C. Siqueira from FAPERJ and V.A.M. from CNPq. Currently V.A.M. is associated to the Programa de Pós-Graduação em Ecologia from Universidade do Estado do Rio de Janeiro and receives a Post-Doctoral grant from FAPERJ (100.005/2009). J. P. Pombal Jr., C. Canedo, D. Baêta, H. R. da Silva, A. M. P. T. Carvalho-e-Silva and C. A. G. Cruz helped us with the identification of the frog species. 
We thank the Instituto Estadual do Ambiente (INEA) for the permit for working at the Parque Estadual do Desengano.

\section{References}

ALMEIDA-GOMES, M., VAN SLUYS, M. \& ROCHA, C.F.D. 2007. Calling activity of Crossodactylus gaudichaudii (Anura: Hylodidae) in an Atlantic Rainforest area at Ilha Grande, Rio de Janeiro, Brazil. Belgian J. Zool. 137(2):203-207.

ALMEIDA-GOMES, M., VRCIBRADIC, D., SIQUEIRA, C.C., KIEFER, M.C., KLAION, T., ALMEIDA-SANTOS, P., NASCIMENTO, D., ARIANI, C.V., BORGES-JUNIOR, V.N.T., FREITAS-FILHO, R.F., VAN SLUYS, M. \& ROCHA, C.F.D. 2008. Herpetofauna of an Atlantic Rainforest area (Morro São João) in Rio de Janeiro State, Brazil. An. Acad. Bras. Ciênc. 80(2):291-300. http://dx.doi.org/10.1590/S000137652008000200007

ALMEIDA-GOMES, M., ALMEIDA-SANTOS, M., GOYANNES-ARAÚJO, P., BORGES-JUNOIR,V.N.T., VRCIBRADIC, D., SIQUEIRA, C.C., ARIANI, C.V., DIAS, A.S., SOUZA, V.V., PINTO, R.R., VAN SLUYS, M. \& ROCHA, C.F.D. 2010. Anurofauna of an Atlantic Rainforest fragment and its surroundings in northern Rio de Janeiro State, Brazil. Braz. J. Biol. 70(3):871-877. http://dx.doi.org/10.1590/S151969842010000400018

ATTIAS, N., RAÍCES, D.S.L., PESSOA, F.S., ALBUQUERQUE, H., JORDÃO-NOGUEIRA, T., MODESTO, T.C. \& BERGALLO, H.G. 2009. Potential distribution and new records of Trinomys species (Rodentia: Echimyidae) in the state of Rio de Janeiro. Zoologia 26(2):305-315. http://dx.doi.org/10.1590/S1984-46702009000200013

BERGALlO, H.G., ROCHA, C.F.D., ALVES, M.A.S. \& VAN SLUYS, M. 2000. A Fauna ameaçada de extinção do Estado do Rio de Janeiro. EdUERJ, Rio de Janeiro, 166p.

BERGALLO, H.G., FIDALGO, E.C.C., ROCHA, C.F.D., UZEDA, M.C., COSTA, M.B., ALVES, M.A.S., VAN SLUYS, M., SANTOS, M.A., COSTA, T.C.C. \& COZZOLINO, A.C.R. 2009. Estratégias e ações para a conservação da biodiversidade no Estado do Rio de Janeiro. Instituto Biomas, Rio de Janeiro, 344p.

BOQUIMPANI-FREITAS, L., MARRA, R.V., ROCHA, C.F.D. \& VAN SLUYS, M. 2002. Ecology of the horned leaf-frog, Proceratophrys appendiculata (Leptodactylidae), in an insular Atlantic Rainforest area of Southeastern Brazil. J. Herpetol. 36(2):318-322.

BOQUIMPANI-FREITAS, L., MARRA, R.V., VAN SLUYS, M. \& ROCHA, C.F.D. 2007. Temporal niche of acoustic activity in anurans: interspecific and seasonal variation in a neotropical assemblage from south-eastern Brazil. Amphib.-Reptilia 28(2):269-276. http://dx.doi. org/10.1163/156853807780202422

CARVALHO-E-SILVA, A.M.P.T., SILVA, G.R. \& CARVALHO-E-SILVA, S.P. 2008. Anuros da Reserva Rio das Pedras, Mangaratiba, RJ, Brasil. Biota Neotrop. 8(1):199-209. http://dx.doi.org/10.1590/S167606032008000100021

CORN, P.S. 1994. Straight-line drift fences and pitfall traps. In Measuring and monitoring biological diversity: standard methods for amphibians (W.R. Heyer, M.A. Donnelly, R.W. McDiarmid, L.A.C. Hayek \& M.S. Foster, eds.). Smithsonian Institution Press, Washington, p.109-117.

CRUMP, M.L. \& SCOTT JUNIOR, N.J. 1994. Visual encounter surveys. In Measuring and monitoring biological diversity: standard methods for amphibians (W.R. Heyer, M.A. Donnelly, R.W. McDiarmid, L.A.C. Hayek \& M.S. Foster, eds.). Smithsonian Institution Press, Washington, p.84-92.

ESBÉRARD, C.E.L., BAPTISTA, M., COSTA, L.M., LUZ, J.L. \& LOURENÇO, E.C. 2010. Morcegos de Paraíso do Tobias, Miracema, Rio de Janeiro. Biota Neotrop. 10(4):249-256.

FAUTH, J.E., CROTHER, B.I. \& SLOWINSKI, J.B. 1989. Elevational patterns of species richness, eveness and abundance of the Costa Rican leaf-litter herpetofauna. Biotropica 21(2):178-85. http://dx.doi. org/10.2307/2388708
GIARETTA, A.A., SAWAYA, R.J., MACHADO, G., ARAÚJO, M.S., FACURE, K.G., MEDEIROS, H.F. \& NUNES, R. 1997. Diversity and abundance of litter frogs at altitudinal sites at Serra do Japi, Southesatern Brazil. Rev. Bras. Zool. 14(2):341-346. http://dx.doi.org/10.1590/S010181751997000200008

GIARETTA, A.A., FACURE, K.G., SAWAYA, R.J., MEYER, J.H.D. \& CHEMIN, N. 1999. Diversity and abundance of litter frogs in a montane forest of southeastern Brazil: seasonal and altitudinal changes. Biotropica 31(4):669-674. http://dx.doi.org/10.1111/j.1744-7429.1999. tb00416.x

GONÇALVES, R.B. \& BRANDÃO, C.R.F. 2008. Diversidade de abelhas (Hymenoptera, Apidae) ao longo de um gradiente latitudinal na Mata Atlântica. Biota Neotrop. 8(4):51-61.

HATANO, F.H., ROCHA, C.F.D. \& VAN SLUYS, M. 2002. Environmental factors affecting calling activity of a tropical diurnal frog (Hylodes phyllodes: Leptodactylidae). J. Herpetol. 36(2):314-318.

HEYER, W.R. \& BERVEN, K.A. 1973. Species diversities of herpetofaunal samples from similar microhabitats at two tropical sites. Ecology 54(3):642645. http://dx.doi.org/10.2307/1935353

JAEGER, R. \& INGER, R.F. 1994. Standard techniques for inventory and monitoring: Quadrat Sampling In Measuring and monitoring biological diversity: standard methods for amphibians (W.R. Heyer, M.A. Donnelly, R.W. McDiarmid, L.A.C. Hayek \& M.S. Foster, eds.). Smithsonian Institution Press, Washington, p.97-102.

LICHT, L.E. 1969. Comparative breeding biology of the red-legged frog (Rana aurora aurora) and the western spotted frog (Rana pretiosa pretiosa) in southwestern British Columbia. Can. J. Zool. 47(4):505-509. http:// dx.doi.org/10.1139/z69-089

LIEBERMAN, S.S. 1986. Ecology of the leaf litter herpetofauna of a Neotropical rainforest: La Selva, Costa Rica. Acta Zool. Mex. 15(1):1-71.

MENIN, M., WALDEZ, F. \& LIMA, A.P. 2008. Temporal variation in the abundance and number of species of frogs in 10,000 ha of a forest in Central Amazonia, Brazil. S. Am. J. Herpetol. 3(1):68-81. http://dx.doi. org/10.2994/1808-9798(2008)3[68:TVITAA]2.0.CO;2

MOÇO, M.K., GAMA-RODRIGUES, E.F., GAMA-RODRIGUES, A.C. \& CORREIA, M.E.F. 2005. Caracterização da fauna edáfica em diferentes coberturas vegetais na região norte fluminense. Rev. Bras. Ciênc. Solo 29(4):555-564.

MODESTO, T.C., PESSOA, F.S., ENRICI, M.C., ATTIAS, N., JORDÃONOGUEIRA, T., COSTA, L.M., ALBUQUERQUE, H., BERGALLO, H.G. 2008. Mamíferos do Parque Estadual do Desengano, Rio de Janeiro, Brasil. Biota Neotrop. 8(4):153-159. http://dx.doi.org/10.1590/S167606032008000400015

MORELLATO, L.P.C. \& HADDAD, C.F.B. 2000. Introduction: the Brazilian Atlantic Forest. Biotropica 32(4b):786-92. http://dx.doi. org/10.1111/j.1744-7429.2000.tb00618.x

MYERS, N., MITTERMEIER, R.A., MITTERMEIER, C.G., FONSECA, G.A.B. \& KENT, J. 2000. Biodiversity hotspots for conservation priorities. Nature 403(6772):853-858. PMid:10706275. http://dx.doi. org/10.1038/35002501

NAVAS, C.A. 1996. The effect of temperature on the vocal activity of tropical anurans: a comparison of high and low-elevation species. J. Herpetol. 30(4):488-497. http://dx.doi.org/10.2307/1565691

PIRATELLI, A., ANDRADE, V.A. \& LIMA-FILHO, M. 2005. Aves de fragmentos florestais em área de cultivo de cana-de-açúcar no sudeste do Brasil. Iheringia, Sér. Zool. 95(2):217-222.

POUGH, H.F., TAIGEN, T.L., STEWART, M.M. \& BRUSSARD, P.F. 1983. Behavioral modification of evaporative water loss by a Puerto Rican frog. Ecology 64(2):244-252. http://dx.doi.org/10.2307/1937072

RIBEIRO, M.C., METZGER, J.P., MARTENSEN, A.C., PONZONI, F.J. \& HIROTA, M.M. 2009. The Brazilian Atlantic Forest: How much is left, and how is the remaining forest distributed? Implications for conservation. Biol. Conserv. 142(6):1141-1153. http://dx.doi.org/10.1016/j. biocon.2009.02.021 
RIBEIRO-JÚNIOR, M.A., ROSSI, R.V., MIRANDA, C.L. \& ÁVILA-PIRES, T.C.S. 2011. Influence of pitfall trap size and design on herpetofauna and small mammal studies in a Neotropical Forest. Zoologia 28(1):80-91. http://dx.doi.org/10.1590/S1984-46702011000100012

ROCHA, C.F.D., VAN SLUYS, M., ALVES, M.A.S., BERGALLO, H.G. \& VRCIBRADIC, D. 2000. Activity of leaf-litter frogs: when should frogs be sampled? J. Herpetol. 34(2):285-287. http://dx.doi.org/10.2307/1565426

ROCHA, C.F.D., VAN SLUYS, M., ALVES, M.A.S., BERGALLO, H.G. \& VRCIBRADIC, D. 2001. Estimates of forest floor litter frog communities: A comparison of two methods. Austral Ecol. 26(1):14-21.

ROCHA, C.F.D., BERGALLO, H.G., ALVES, M.A.S. \& VAN SLUYS, M. 2003. A biodiversidade nos grandes remanescentes florestais do estado do Rio de Janeiro e nas restingas da Mata Atlântica. RiMa, São Carlos, 160p.

ROCHA, C.F.D., BERGALLO, H.G., POMBAL JUNIOR, J.P., GEISE, L., VAN SLUYS, M., FERNANDES, R. \& CARAMASCHI, U. 2004. Fauna de anfíbios, répteis e mamíferos do Estado do Rio de Janeiro, sudeste do Brasil. Publ. Avul. Mus. Nac. 104:3-23.

ROCHA, C.F.D., VRCIBRADIC, D., KIEFER, M.C., ALMEIDA-GOMES, M., BORGES-JUNIOR, V.N.T., CARNEIRO, P.C.F., MARRA, R.V., SANTOS, P.A., SIQUEIRA, C.C., GOYANNES-ARAÚJO, P., FERNANDES, C.G.A., RUBIÃO, E.C.N. \& VAN SLUYS, M. 2007. A survey of the leaf-litter frog community from an Atlantic forest area (Reserva Ecológica de Guapiaçu) in Rio de Janeiro State, Brazil, with an estimate of frog densities. Trop. Zool. 20(1):99-108.

SALLES, R.O.L., WEBER, L.N. \& SILVA-SOARES, T. 2009. Amphibia, Anura, Parque Natural Municipal da Taquara, municipality of Duque de Caxias, state of Rio de Janeiro, southeastern Brazil. Check List 5(4):840-854.
SCOTT JUNIOR, N.J. 1976. The abundance and diversity of the herpetofauna of tropical forest litter. Biotropica 8(1):41-58. http://dx.doi. org/10.2307/2387818

SILVA, H.R., CARVALHO, A.L.G. \& BITTENCOURT-SILVA, G.B. 2008. Frogs of Marambaia: a naturally isolated Restinga and Atlantic Forest remnant of southeastern Brazil. Biota Neotrop. 8(4):167-174. http:// dx.doi.org/10.1590/S1676-06032008000400017

SIQUEIRA, C.C., VRCIBRADIC, D., ALMEIDA-GOMES, M., BORGESJUNIOR, V.N.T., ALMEIDA-SANTOS, P., ALMEIDA-SANTOS, M., ARIANI, C.V., GUEDES, D.M., GOYANNES-ARAÚJO, P., DORIGO, T.A., VAN SLUYS, M. \& ROCHA, C.F.D. 2009. Density and richness of leaf litter frogs (Amphibia: Anura) of an Atlantic Rainforest area in the Serra dos Órgãos, Rio de Janeiro State, Brazil. Zoologia 26(1):97-102.

SIQUEIRA, C.C., VRCIBRADIC, D., DORIGO, T.A. \& ROCHA, C.F.D. 2011. Anurans from two high-elevation areas of Atlantic Forest in the state of Rio de Janeiro, Brazil. Zoologia 28(4):457-464.

TONHASCA JUNIOR, A., BLACKMER, J.L. \& ALBUQUERQUE, G.S. 2002. Abundance and diversity of Euglossine bees in the fragmented landscape of the Brazilian Atlantic Forest. Biotropica 34(3):416-422.

van SLUYS, M., VRCIBRADIC, D., ALVES, M.A.S., BERGALLO, H.G. \& ROCHA, C.F.D. 2007. Ecological parameters of the leaf-litter frog community of an Atlantic Rainforest area at Ilha Grande, Rio de Janeiro State, Brazil. Austral Ecol. 32:254-260. http://dx.doi.org/10.1111/j.14429993.2007.01682.x

VAZ, S.M. 1998. Primates in the Desengano State Park, Rio de Janeiro, Brazil. Neotrop. Primates 6(4):127-128.

WEBB, G.A. 1999. Effectiveness of pitfall/drift-fence systems for sampling small ground-dwelling lizards and frogs in southeastern Australian forests. Austr. Zool. 31(1):118-126. 


\section{Appendix}

Appendix 1. Voucher specimens of species collected in the present study deposited at the Museu Nacional, Rio de Janeiro (MNRJ) and at the Universidade Federal do Estado do Rio de Janeiro (UNIRIO).

Aplastodiscus cf. arildae: UNIRIO 2787; Brachycephalus sp.: MNRJ 42407-9; Hypsiboas polytaenius: MNRJ 54537-8; Ischnocnema guentheri: MNRJ 55844-9, UNIRIO 3865; Ischnocnema octavioi: MNRJ 42488; Ischnocnema parva: MNRJ 64244-328;

Phasmahyla guttata: MNRJ 51811; Proceratophrys melanopogon: MNRJ 54017; Rhinella icterica: MNRJ 55482; Scinax v-signatus: MNRJ 57299-307. 
